\title{
破壊力学手法に基づく繊維補強セメント系複合材料の力学的特性 に関する一考察 \\ MECHANICAL PROPERTIES OF FRCC ON THE BASIS OF FRACTURE MECHANICS
}

\author{
三橋博三*, 野村希晶**, 桐 越一紀*** \\ Hirozo MIHASHI, Noriaki NOMURA and Kazuki KIRIKOSHI
}

\begin{abstract}
Toughening mechanism and strengthening mechanism of composite materials reinforced with short fibers have been studied on the basis of fracture mechanics. Tension softening diagram is related to the failure properties and some experimental results are shown to discuss how the properties of fibers and matrix influence the tension softening diagram of the concrete. Validity of a simplified technique to determine the tension softening diagram is also discussed. It is concluded that not only the fracture toughness but also the tension softening properties should be evaluated to understand the reinforcing mechanism and to apply the knowledge to the development of new cementitious composite materials.
\end{abstract}

Keywords : fiber reinforced, fracture mechanics, tension softening, fracture toughness 瀻維補強, 破壊力学, 引張軟化則, 破壊靱性

\section{1. 序}

コンクリートやモルタルの対引張応力下での補強手段 として，各種瀻維材料を用いた繊維補強セメント系複合 材料 (FRCC) が開発され実用化も進んでいる。

複合材料の特性は, 混入瀻維の剛性・強度, 䋐維の径・ 長さ・形状, 混入量, 混入時の繊維の方向, 繊維一母材 界面間の強度など，種々の要因に支配される。このよう な FRCC の引張強度推定式として, 複合則に基づく次 式が用いられる”。

$$
\left.\begin{array}{ll}
F_{u}=\alpha_{1} \alpha_{2} \sigma_{f} V_{f}+F_{m}^{e}\left(1-V_{f}\right): & {\left[V_{f}<V_{f}^{c r}\right]} \\
F_{u}=\alpha_{1} \alpha_{2} F_{f} V_{f} & :\left[V_{f}>V_{f}^{c r}\right]
\end{array}\right\} \cdots
$$

ここで， $\alpha_{1}$ および $\alpha_{2}$ は，それぞれ，瀻維の方向と有 効瀻維長さの影響を表す実験定数; $V_{f}$ は瀻維の体積率; $\sigma_{f}$ は母材ひび割れ時の繊維負担応力; $F_{f}$ は繊維の引張 強度; $F_{m}^{e}$ は母材の有効引張強度である。この種の実験 式は実用的な反面，その妥当性は実験に用いられた材料 および試験の範囲に限られたものになる。また, 複合材 料の性能を引き出すためには, その巨視的な挙動を下位 概念である微視的挙動を介して説明すべきだが，この害 験式は微視的な挙動およびメカニズムを記述しているわ けではない。したがって, 繊維と母材の特性を材料全体
の破壊特性に関係づける一般的なモデルを開発すること が重要になってくる。また，巨視的な挙動の予測および 新しい複合材料の設計の基礎になるデータベースを充実 させるためには標準試験法を確立することも重要な課題 である。このような観点から有用な方法のひとつとして 破壊力学的アプローチが挙げられる。破壊力学的手法を 用いることにより，破壊鞀性や強度なごの巨視的破壊特 性と微視的な破壊機構を関係づけることが可能にな $3^{2) .31}$ 。

FRCC の力学的特性を把握するうえで, 破壊靶性ば かりではなく, 引張域での応力が最大值に達した後の変 形挙動である引張軟化特性も同時に評価する必要があ る。これは引張軟化則は単に破壊䩲性の評価に用いるば かりでなく,FRCCを用いた部材レベルの力学的特性 の予測をも可能性にするからである。引張軟化則に着目 した破壊力学概念をFRCCに適用した研究としては,

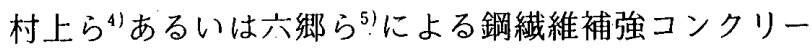
トの靱性向上を引張軟化則の変化として示したもの, $\mathrm{Li} ら^{6)}$ の種々の瀻維補強モルタルの引張軟化則をモルタ ルと比較したもの, などが挙げられる。三橋”は, 引張 軟化特性が全体の力学的挙動に及ぼす影響を考察する一
* 東北大学工学部 $\cdot$ 助教授 $\cdot$ 工博

*** 東北大学工学部 助手. 工博

*** 東北大学工学部 教務技官
Assoc. Prof., Faculty of Engineering, Tohoku Univ., Dr. Eng. Research Assoc., Faculty of Engineering, Tohoku Univ., Dr. Eng. Tech. Assistant, Faculty of Engineering, Tohoku Univ. 
表一1 調合条件

\begin{tabular}{|l|ccccc|}
\hline Series & W/C & S/C & $\begin{array}{c}\text { Silica- } \\
\text { fume }\end{array}$ & Fiber & $\begin{array}{c}\text { Super- } \\
\text { plasticizer }\end{array}$ \\
\hline MTR-1 & 0.40 & 1.5 & & & \\
\hline MTR-2/Si & 0.40 & 1.5 & $30 \%$ & & \\
\hline FRM-1/PAN & 0.40 & 1.5 & & Carbon/PAN 3 \% & $3 \%$ \\
\hline FRM-2/PAN/Si & 0.40 & 1.5 & $30 \%$ & Carbon/PAN 3 \% & $3 \%$ \\
\hline FRM-3/pitch/Si & 0.40 & 1.5 & $30 \%$ & Carbon/pitch 3 $\%$ & $3 \%$ \\
\hline FRM-4/PVA/Si & 0.40 & 1.5 & $30 \%$ & Vinylon 3 $\%$ & $3 \%$ \\
\hline
\end{tabular}

方で，いくつかのセメント系複合材料の引張軟化特性を 実験により求め, 複合材料の設計指標について考察を加 えている。

本論文は，短繊維によって補強されたFRCC の高靱 性化と高強度化について, 引張軟化特性と破壊特性の関 係に着目して論じるものである。さらに，瀻維と母材の 特性が材料の引張軟化特性に与える影響を検討する。ま た，FRCC のような高勒性材料の引張軟化則を決定す るための簡易手法である新 $J$ 積分法淿についても検討を 加える。

\section{2. 実験および解析方法}

\section{1 実験方法}

繊維および母材と引張軟化則の関係を調べるために， 表一1に示すような数種類のセメント系複合材料の破壊 エネルギ式験を行った。使用した材料は早強ポルトラン ドセメントと 7 号硅砂である。最大骨材粒径は約 0.42 $\mathrm{mm}$ で骨材の $75 \%$ 以上が $0.105 \mathrm{~mm}$ から $0.42 \mathrm{~mm}$ の範 囲にある。水セメント比は 0.40 ，砂セメント比は 1.5 である。使用した繊維は, PAN 系炭素瀻維 (FRM-1, FRM-2)，ピッチ系炭素繊維（FRM-3），および高弾 性ビニロン（PVA）の 3 種類である。これら，各繊維 の長さはすべて $6 \mathrm{~mm}$ で，混入率は体積当たり $3 \%$ で ある。表一2には，使用した繊維の特性をまとめた。

試験体は100 mm × $100 \mathrm{~mm} \times 50 \mathrm{~mm}$ の形状の CT (Compact Tension) 試験体で，鋼製型枠を用いて製 作した。打設後 24 時間で脱型し $47^{\circ} \mathrm{C}$ の養生槽で 24 時

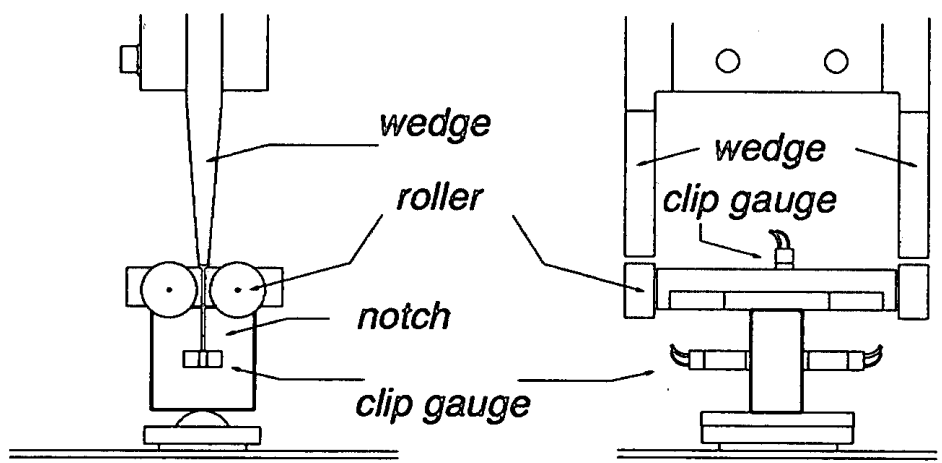

図一1 載荷方法
間湿空養生したのち， 7 日間 $20^{\circ} \mathrm{C}$ の水中養生を施した。 切欠はダイヤモンドカッターで成形した。載荷は図一1 に示すような wedge-split 型とし，サーポコントロール 型の疲労試験機を用いて行った。

\section{2 引張軟化則の評価法}

CT 試験からは最大荷重以降の下降域を含む荷重-変 位曲線が求められるが，これを最適化する引張軟化則を 逆解析により決定することができる ${ }^{2), 88}$ 。実験の結果得 られる荷重-変位曲線を数值化したものを $F_{E}(i) ;(i=1$, $\cdots, r)$ と書く。変位としては荷重点変位や開口変位な ぞ原理的には任意の位置の変位でよい。また，パラメー 夕 $|x|$ を持つ引張軟化モデルを仮定し，これを用いて計 算される同種の荷重一変位曲線を $F_{M}(i ;|x|)$ とすると, 次の最小 2 乗法によって引張軟化モデルの形状を表すパ ラメータ $\{x\}$ を定めることができる。

$$
S(|x|)=\sum_{i=1}^{r}\left[F_{E}(i)-F_{M}(i ;|x|)\right]^{2} \rightarrow \min
$$

ここで，S(\{x\}) は実験と計算の荷重-変位曲線間の誤差 の二乗和である。FRCC のような高勒性材料は引張軟 化則の最大開口変位 $w_{2}$ が大きく，そのような場合の荷 重一変位曲線を計算する方法のひとつを付録に示した。

さて，コンクリートの引張軟化則を, パラメータ $F_{\ell}$, $s_{1}, w_{1}, w_{2}$ によって規定される図一2 のような 2 直線近 似モデルで表現すると，式（2）の $|x|$ は，

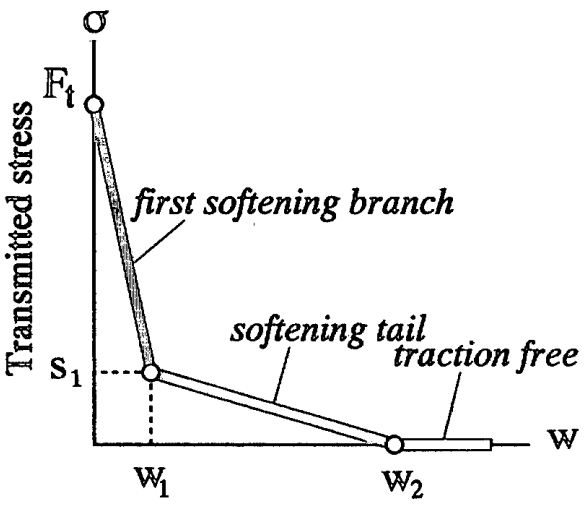

Opening displacement

图一2 引張軟化則の 2 直線モデル 
表一2 使用した緎維の特性

\begin{tabular}{|l|l|rrrr|}
\hline Fiber & Type & length $(\mathrm{mm})$ & Young's Modulus (MPa) & strength (MPa) & Elongation \\
\hline Carbon & PAN & 6.0 & 235000 & 4217 & 1.8 \\
\hline Carbon & pitch & 6.0 & 33000 & 790 & 2.4 \\
\hline PVA & Vinylon-AA & 6.0 & 39500 & 1834 & 6.7 \\
\hline
\end{tabular}

$|x|=\left\{F_{t}, s_{1}, w_{1}, w_{2}\right\}$

と書ける。こうして得られる 2 直線近似引張軟化モデル のパラメータから, 単位面積のひび割れ領域が進展する ために必要なエネルギである破壊エネルギ $G_{s}$ は，引張 軟化曲線の帇む面積として次式で求められる。

$$
G_{f}=\left(F_{\imath} w_{1}+s_{1} w_{2}\right) / 2
$$

\section{3 引張軟化則の簡易評価法}

上に述べた引張軟化則を求める最適化手法は，パラメ トリックに設計された材料の引張軟化則を求めるうえ で，有効な方法であるが，非線形問題を解く必要がある 点が実用上の難点である。これに対し，実験的に引張軟

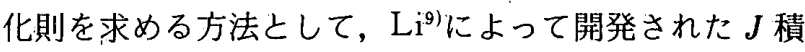
分に基づく引張軟化則評価手法と，この改良版である六 郷ら ${ }^{10)}$ の新 $J$ 積分法がある。これらを概説する。まず 結合力モデルの $J$ 積分を算出すると, 切欠先端の伝達 応力 $(\sigma)$-開口変位 $(w)$ 関係亡 $J$ 積分は次の関係にあ る。

$$
J(w)=\int_{0}^{w} \sigma(w) d w
$$

したがって，伝達応力 $(\sigma)$-開口変位 $(w)$ 関係，すな わち引張軟化則は次式で与えられる。

$$
\sigma(w)=\frac{\partial J(w)}{\partial w}
$$

実験的に $J$ 積分は，切欠長さのわずかに異なる 2 体の 試験体の荷重-荷重点変位を記録して次式で求められる。

$$
J(d)=\frac{1}{B\left(a_{2}-a_{1}\right)} \int_{0}^{d}\left\{P_{1}(\Delta)-P_{2}(\Delta)\right\} d \Delta
$$

ここで, $a_{1}, a_{2}$ は切欠長さ $\left(a_{1}<a_{2}\right), P_{1}(\Delta), P_{2}(\Delta)$ はそれぞれの荷重-変位曲線である。実験時に, 荷重-変 位曲線とともに荷重-開口変位曲線を記録しておくこと で, 変位と開口変位は実験的な関数関係 $w(\Delta)$ として求 められるから, 式 $(7)$ を開口変位 $w$ の関係に直し, 式（6）を適用できる。

この方法は, 実験的に引張軟化則を求めうる妥当な方 法であるが， 2 体の試験体を必要とすることや，わずか な切欠長さの差を持つ試験の結果がバラツキの影響を受 けやすい点が難点である。それに対し，六郷らの新 $J$ 積分法 ${ }^{10}$ :は, 一方の切欠長さを仮想的にリガメント全体 を貫いているものと考え， $P_{2}(\Delta)=w(\Delta)=0$ と見なして Li らの方法を適用したもので, 1 体の試験体で引張軟 化則が求められるようになっている。本論文では，この 六郷らの方法によって FRCC の引張軟化則を求め, 最 適化による方法と比較検討する。

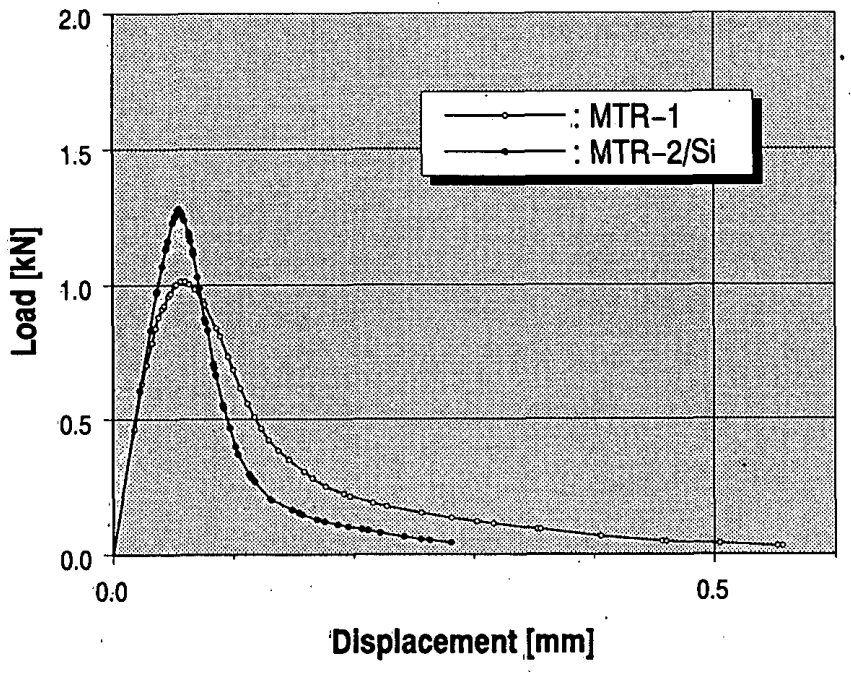

図一3 モルタルの荷重変位曲線

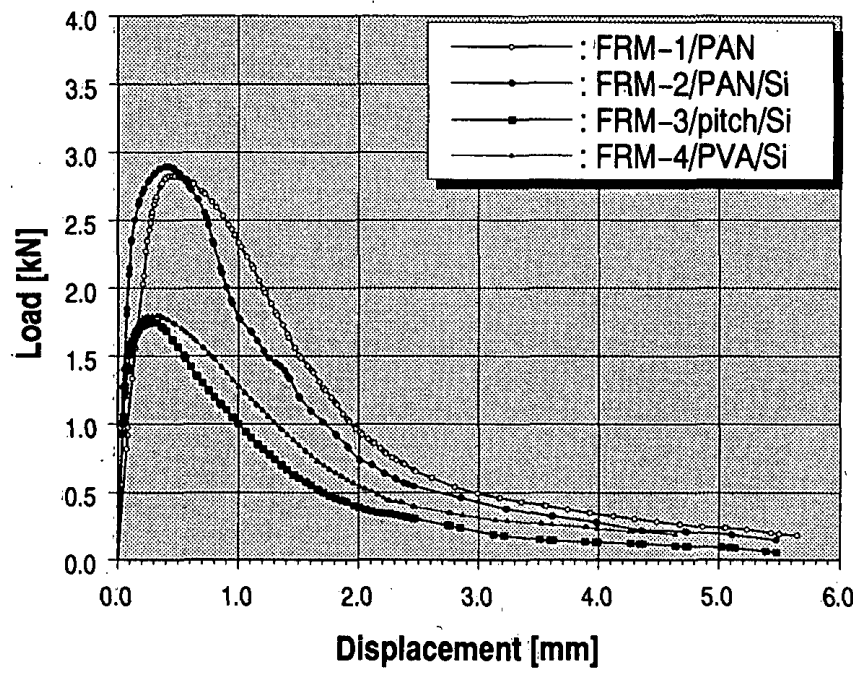

図一4䋞維補強モルタルの荷重変位曲線

\section{3. 結果および考察}

実験によって得られた各シリーズの荷重一変位曲線を 図一 3 と図一 4 に示した。これらは，各シリーズについ てそれぞれ 3 本の荷重-変位曲線を数值化した後に平均 化したものである。これらの図では, 繊維補強モルタル の横軸がモルタルの 10 倍になっていることに注意する 必要がある。各シリーズについて，それぞれ 3 本の荷重 一変位曲線を用いて求めた引張軟化則モデルのパラメー 夕の平均值を表一 3 に, またその引張軟化則そのものを 図一 5 に示す。全般にこの実験の範囲では，繊維の混入 によって通常のモルタルに比べて 30〜40 倍以上高い靫 性を確保するようになったといってよい。ところで，荷 
表一3 推定された引張軟化則モデルパラメータ

\begin{tabular}{|l|r|r|r|r|r|r|}
\hline \multicolumn{1}{|c|}{ Series } & $E(\mathrm{MPa})$ & $G_{f}(\mathrm{~N} / \mathrm{m})$ & $F_{t}(\mathrm{MPa})$ & $s_{1}(\mathrm{MPa})$ & $w_{1}(\mathrm{~mm})$ & $w_{2}(\mathrm{~mm})$ \\
\hline MTR-1 & 28600 & 60 & 3.3 & 0.32 & 0.02 & 0.12 \\
\hline MTR-2/Si & 30000 & 41 & 7.6 & 0.62 & 0.01 & 0.03 \\
\hline FRM-1/PAN & 13200 & 2410 & 6.8 & 0.36 & 0.56 & 2.90 \\
\hline FRM-2/PAN/Si & 30600 & 2080 & 6.3 & 0.52 & 0.51 & 1.87 \\
\hline FRM-3/pitch/Si & 24400 & 1110 & 3.7 & 0.49 & 0.42 & 1.38 \\
\hline FRM-4/PVA/Si & 26300 & 1430 & 3.8 & 0.43 & 0.55 & 1.86 \\
\hline
\end{tabular}

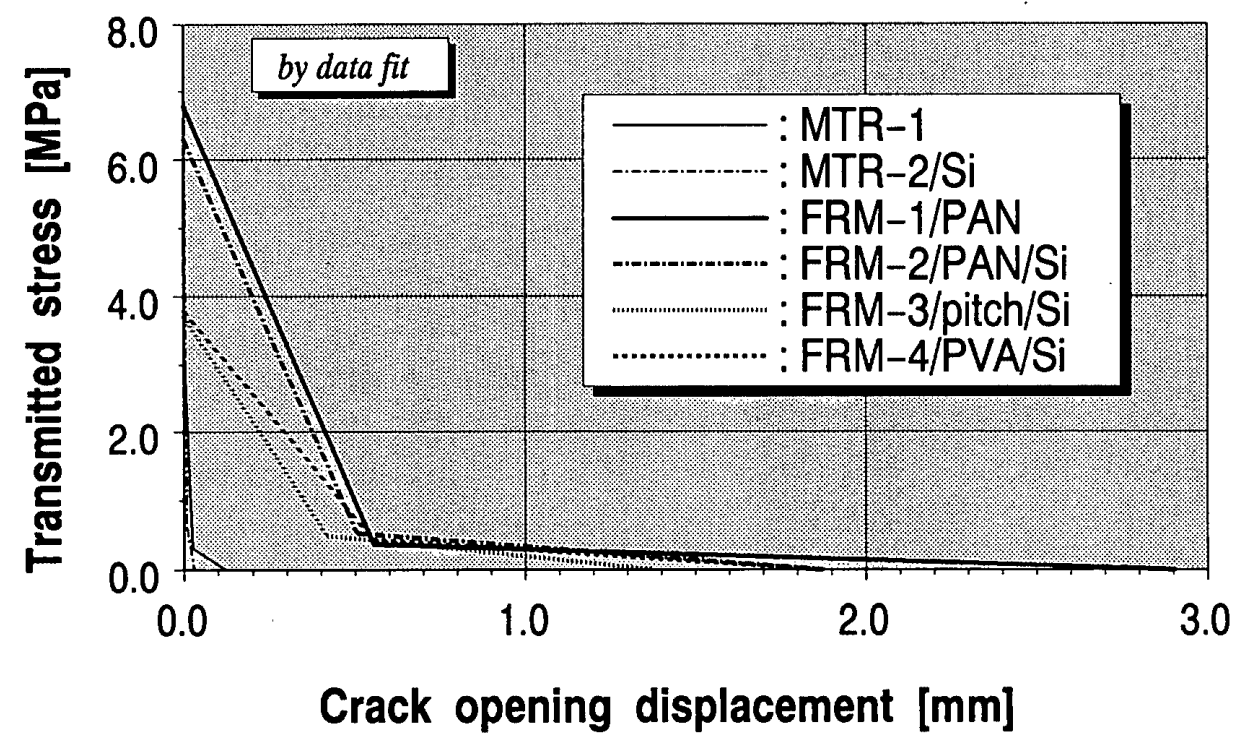

图一5推定された引張軟化則モデル

重-変位曲線から推定される見かけの曲げ強度の特性と は全く違った傾向が軟化開始応力 $\left(F_{t}\right)$ に認められる。 また，同じ母材であっても，混入する繊維によって荷重一 変位曲線や最大荷重の大きさは全く異なっているが, そ の原因は荷重-変位曲線そのものからは探ることができ ない。まさにこの点が, 破壊力学手法に基づいて, FRCC の力学的特性を論ずる重要なポイントとなる。

シリカフュームを混入したモルタル（MTR-2/Si） はこれらの中で最も高い $F_{t}$ を有しており，この值は未 混入モルタルのそれに比べて 2.3 倍にも達している。こ のことは, 微細構造の緻密さが $F_{t}$ の值に大きく関与し ていることを示している。しかしながら，このモルタル の破壊勒性は逆に全シリーズで最も小さくなっている。 一方，シリカフュームを混入しないPAN 系炭素緎維補 強モルタル (FRM-1/PAN) は, 低弾性ではありながら, 最も高い鞀性と, その母材の約 2 倍にも達する $F_{t}$ 值を 示している。同程度の最大開口変位 $\left(w_{2}\right)$ を有する場 合には， $F_{\imath}$ の増大が FRCC の最大曲げ荷重を引き上げ るための最も効率のよい方法といえる7が, FRM-1/ PAN のような軟化開始応力の著しい増大は, 鋼瀻維補 強の場合には得られない要ことから，母材内に分散した 繊維の太さが重要な因子となっていることがわかる。
FRM-1 とその母材が同じ MTR-1 を比較すると, 緎 維を混入した場合の方が $F_{t}$ は大きくなっている。これ に対して，FRM-2，3，4のそれぞれとその母材が同じ である MTR-2を比較すると，逆に瀻維を混入した場 合の方が $F_{t}$ は小さくなっている。これは，混入する繊 維が微視的破壊機構に対して 2 つ作用を有するためと 考えられる。すなわち, 䋐維と母材の剛性の差異が大き くなると, 繊維は専らひび割れの抵抗機構（アレスタ） として働く。これが, FRM-1の $F_{t}$ が大きくなった理 由である。その一方で, 特に繊維の剛性がそれほど高く ない場合には，母材中に埋め込まれた纎維はある種の久 宿としても振舞うと考えられる。したがって, FRM-2, 3, 4 の $F_{t}$ が MTR-2 のそれより小さくなり， 特に，相対的に剛性の小さいFRM-3/pitch-Si と FRM-4/PVA-Si ではその傾向が顕著になっている。

さらに図一4を見ると，繊維の混入により $F_{t}$ 増大の ほかにも, 開口変位 $w$ の大幅な増大と, 引張軟化則の 第 1 軟化勾配が著しく緩やかになり 2 直線引張軟化モデ ルの前半部分が規定する破壊エネルギ゙が全体の破壊工 ネルギの中で大きな割合を占めるように変化している点 が注目される。 $w$ の增大は，ひび割れ面に介在する繊 維によって応力が伝達され変形抵抗が増大する，いわゆ 


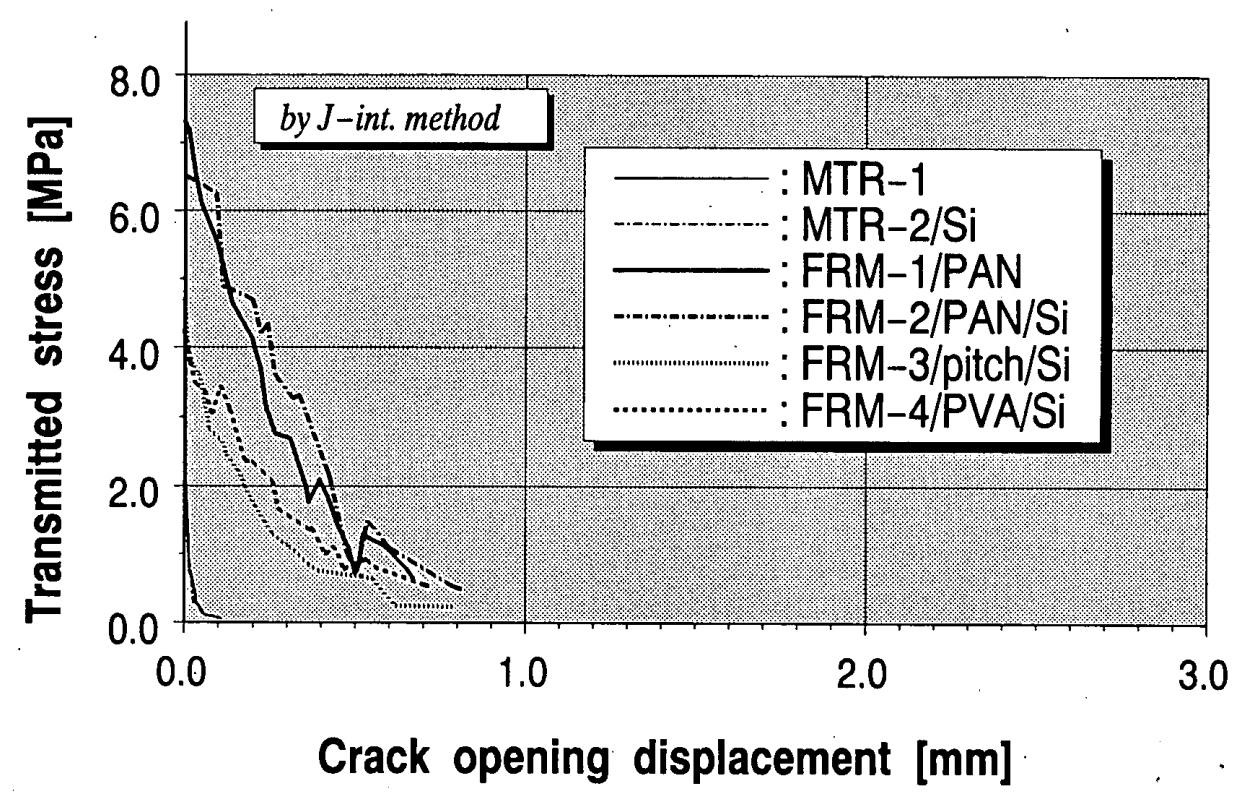

図一6 新 $J$ 積分により求められた引張軟化則

るブリッジングに起因するものと考えられ, 後述する破 面の変化となって現れている。一方, 繊維混入による第 1 軟化勾配の緩和現象は, 第 1 軟化勾配を規定する破壊 過程には, 微細ひび割れの発生だけではなく, 複数の微 細ひび割れが成長・連結し連続ひび割れが生成される過 程が含まれていることを意味している。それは次のよう な理由による。即ち, 微細ひび割れの発生は骨材一母材 間の界面から始まると考えられるが，いったん形成され た微細ひび割れが母材内に連結・成長する際には母材内 の繊維に遭遇するはずであり，母材-繊維間の付着部分 を通過して進まなければならず，それが微細ひび割れ領 域の拡大を導き，進展の抵抗力を上げるものと考えられ る。その結果, 2 直線引張軟化モデルの第 1 軟化勾配が 瀻維の混入によって緩やかに変化し，FRCC に高靵性 を付与するものと考えられる。第 2 軟化勾配の伝達応力 レベルは第 1 軟化勾配のそれと比べて極めて低いので, この材料の鞁性を高めるメカニズムが繊維のブリッジン グ効果のみとは考えにくく, むしろ荷重-変位曲線の延 性にブリッジングが笴与していると考えるのが妥当であ る。

もちろん, 第 1 軟化勾配の特性は 2 直線引張軟化モデ ルについての性質であるから，それは平均的な意味での 特性を指すものであり, 上述の議論は, 厳密には, 第 1 軟化勾配部分が微細ひび割れの発生と連結・成長の機構 に基づく変形特性に近似的に対応するという意味であ る。

破断後の破面を観察すると, 一般にモルタルは比較的 平坦な破面を特ち, 瀻維補強モルタルは粗い破面になっ ている。特に, PAN 系炭素蠘維とビニロン繊維の場合 には，繊維の端部が破断面に数多く現れる。したがって， 繊維の抵抗機構による粗い破面は，ひび割れの枝分かれ
や曲がり進みにより生じると考えられ，これが最大開口 変位 $w_{2}$ の值を大きくしていると思われる。繊維と母材 間での剛性や強度の違いは付着劣化を引き起こし，これ もまた $w_{2}$ を增大させる要因になると考えられる3!。

本実験結果に新 $J$ 積分法を適用して求めた引張軟化 則を図一6に示す。この図と最適化手法で求めた引張軟 化則（図一5）を比較すると, 繊維補強モルタルに関し ては，両者は非常によく調和した結果を示している。た だし, プレーンモルタルの軟化開始応力 $F_{t}$ は新 $J$ 積分 法による結果が異常に高い。これは，もともと $J$ 積分 法による軟化開始応力の值は荷重-変位曲線のピーク付 近の形状に鋭敏なためである。即ち, 䋐維補強モルタル に比べ相対的に脆性なプレーンモルタルのような材料で は得られた軟化開始応力の值は，信頼性に欠ける結果と なり易い。また本論文では，新 $J$ 積分法を用いる際に Li ら ${ }^{9}$ が施したような関数近似をデータ処理に用いてい ないので, 引張軟化則の形状は生の荷重-変位曲線の影 響で凹凸のあるものになっているが，ここに用いられた ように十分に大きな破壊プロセスゾーンを形成する FRCC の引張軟化則の簡易評価法として新 $J$ 積分法が 定性的かつ定量的に十分信頼できるものであるといえ る。

一方，逆解析に基づくパラメー夕推定法において，あ らかじめ仮定した 2 直線モデルの FRCCに対する引張 軟化則モデルとしての妥当性は, 図一 5 と図一6の調和 性により裏付けられたと考えられる。

\section{4. 結 論}

繊維補強セメント系複合材料 (FRCC) の高靶性化 および高強度化を評価するために破壊エネルギ試験を行 い, あわせてこれらの材料の引張軟化特性を求めた。さ 
らに引張軟化則のパラメータから瀻維混入による補強の メカニズムの説明を試み, 以下の結論を得た。

1. 繊維補強モルタルの引張軟化挙動の特性から, 第 1 軟化勾配部分が微細ひび割れの発生だけの物理現象に支 配されているわけではなく，微細ひび割れが連続ひび割 れに連結・成長する過程をも含むと考えることの妥当性 が示された。

2. 引張軟化則を比較的簡便に求める新 $J$ 積分法を FRCCに適用した結果は，最適化手法による結果と調 和的であることから，この方法は本研究の対象とした程 度の高靭性材料に対しては㬰用的な簡易評価法として用 い得ることを明らかにした。

謝 辞

本研究を実施するに際し，試料の御提供を頂いた旭化 成カーボンファイバー (株), 呉羽化学工業 (株), 藤沢 薬品工業（株），前田製管（株）ならびにユニチカ（株） の各社に，記して謝意を表します。

\section{付 録}

著者らは先に，巨視ひび割れ伸展線上（リガメント）に軟化 領域が進展しくゆく場合の荷重-変位曲線を求める離散解析手法 を定式化した ${ }^{2)}$ 。しかし，繊維補強コンクリートのように極め て変形能が高い場合には，その引張軟化則も最大開口変位が大 きなものになり，軟化領域がリガメント上を進展し切った後も 織維の存在のためにしばらく荷重を保持しつつ変形することが 予想される。したがって，軟化開始応力に達した節点を次々に 進展させるアルゴリズムだけでは最大荷重後の荷重-変形曲線を 完全には追跡できない。そこで，先の定式化に軟化進行過程の 新たなアルゴリズムを追加し，瀻維補強コンクリートのような 変形能の大きい材料の荷重-変位曲線をシミュレートできるよう にする。

切欠を有する構造物の切欠と巨視ひび割れ伸展線上（リガメ ント）を付図一1のように離散化した場合，離散化点には引張 軟化則モデルに従う結合力 $|p|$ が作用し，その点の開口変位が $|w|$ で表されるものとする。この時, $\{p\}$ と $\{w\}$ は次の関係にある。 $\{w\}=[F]\{p\}+\{C\} q+\{D \mid$

ここに, $[F] ： p$ による撓性行列，すなわち $F_{l}$ は $j$ 点にのみ単 位結合力をかけた時の $i$ 点の開口変位, $q$ : 破壊進行の主なる 外乱であるところの集中外力, $|C|: q$ による撓性ベクトル，す なわち $\mathrm{Ci}$ は単位集中外力をかけた時の $i$ 点の開口変位, $|D|$ : 自重など集中外力以外の一定值の荷重によって生じる撓性，す なわち付加的開口変位、である。式（1）をひび割れの撓性方 程式と呼ふ。

引張軟化の現象は, 上式に結合力-開口変位間の構成関係 $\sigma_{i}=$ $\sigma_{i}\left(w_{i}\right)$ として導入される。 $\sigma_{l}$ は離散化点には力 $p_{i}$ として作用す るので,

$$
p_{i}\left(w_{i}\right)=A_{i} \sigma_{i}\left(w_{i}\right)
$$

と変換する。ここで，A，㰚散化結合点の支配面積である。

先の定式化によれば，軟化開始応力 $F_{2}$ に達する離散化節点が 切欠先端からリガメント上に進行し, 最後の離散化節点 $n$ に達 した時点で, 引張軟化挙動の計算は打ち切られる。この状態か らさらに軟化挙動が進むとすれば，それは，最後の離散化節点 が $F_{\imath}$ に達した後に, 軟化状態にある離散化節点で伝達応力が次

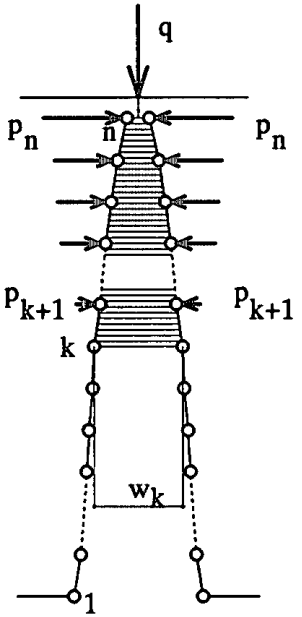

付図一1 離散化されたリガメント

第に減少しそれに伴って開口変位が増大する過程ととらえるこ とができる。離散化モデルに当てはめてみると，これは，切欠 側から応力伝達がまだ可能な離散化節点の伝達応力を 0 に開放 してゆくと同時に，その離散化節点の開口変位を最大開口変位 $w_{2}$ にすることに相当する。

付図一1のように, 忘力伝達が可能な $k$ から $n$ までの離散化 節点のうち, 切欠に最も近い離散化節点 $k$ について, その伝達 応力を 0 に解放し, 開口変位を最大開口変位 $w_{2}$ にした状態を 考える。この場合, 切久部分で伝達応力が働かない, 離散化節 点 $k$ で, 開口変位量は最大開口変位 $w_{2}$, 伝達応力は開放, 離散 化節点 $k$ より前方のリガメント部分では, 伝達応力と開口変位 の関係は引張軟化則に従う，ということなので，ひび割れの撓 性方程式における境界条件之拘束条件は，次の上うに書ける。

境界条件 $p_{j}=0 ; j=1,2, \cdots, k \cdots \cdots \cdots \cdots \cdots \cdots \cdots \cdots \cdots \cdots \cdots \cdots \cdots \cdots(3)$

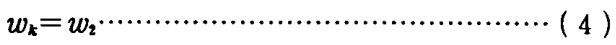

拘束条件 $p_{j}=A_{j} \sigma_{j}\left(w_{j}\right) ; j=k+1, \cdots, n \cdots \cdots \cdots \cdots \cdots \cdots(5)$ これを撓性方程式（1）に代入し，(k-1) 行で分解した後, $\left\{C_{l}\right\}$ と $\left\{F_{i \downarrow}\right\}$ を交換すると次のようになる。$$
\left|\begin{array}{c}
w_{k} \\
\dot{w}_{k+1} \\
\vdots \\
w_{n}
\end{array}\right|=\left[\begin{array}{cccc}
C_{k} & F_{k, k+1} & \cdots & F_{k n} \\
C_{k+1} & F_{k+1, k+1} & \cdots & F_{k+1, n} \\
\vdots & \vdots & & \vdots \\
C_{n} & F_{n, k+1} & \cdots & F_{n n}
\end{array}\right]
$$$$
\left.\times\left\{\begin{array}{c}
q \\
A_{k+1} \sigma_{k+1} \\
\vdots \\
A_{n} \sigma_{n}
\end{array}\right\}+\mid \begin{array}{c}
D_{k} \\
D_{k+1} \\
\vdots \\
D_{n}
\end{array}\right\}
$$

ここで， $w_{i}$ と $\sigma_{i}$ が 1 次関数で記述されるモデルであるとし， これを次のように書くことにする。

$$
w_{k+\iota}=\beta_{k+\imath} X_{k+\iota}+\alpha_{k+i} ; i=0,1, \cdots, m-1
$$
ただし，

$X_{k+\imath}=A_{k+\iota} \sigma_{k+i}$

このとき，式（6）に式（7）を代入して書き換えて $w_{k+\imath}$ を 消去でき，次式になる。

$$
\left.\mid \begin{array}{c}
0 \\
0 \\
\vdots \\
0
\end{array}\right\}=\left[\begin{array}{cccc}
C_{k} & F_{k, k+1} & \cdots & F_{k n} \\
C_{k+1} & \bar{F}_{k+1, k+1} & \cdots & F_{k+1, n} \\
\vdots & \vdots & & \vdots \\
C_{n} & F_{n, k+1} & \cdots & \bar{F}_{n n}
\end{array}\right]
$$




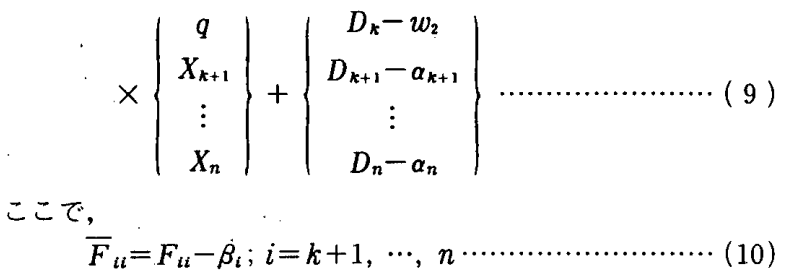

この式が応力伝達をする節点を解放させることによるひび割れ の離散化方程式であり，末知量 $\left\{\left.q X_{k+1} \cdots X_{n}\right|^{T}\right.$ を解として求める ことができる。また，指標 $k$ を進めながら解くことにより荷重変位曲線を数値的に求めることができる。

\section{参考文献}

1) Bentur, A. and Mindess, S., : Fiber Reinforced Cementitious Composites, Elsevier Applied Science, 1990.

2）野村希晶，三橋博三，鈴木 篤，和泉正哲：非線形破壊 力学手法に基づく高強度コンクリートの脆性化機構の考 察, 日本建築学会構造系論文報告集, 第 416 号, pp. 9 16, 1990.

3）野村希晶, 三橋博三，和泉正哲：コンクリートの引張軟 化挙動と破壊エネルギ吸収機構に関する一考察, 日本建 築学会構造系論文報告集，第 438 号，pp.9－14，1992.

4）村上 聖, 岸谷孝一，平居孝之：コンクリートの破壊力 学に関する研究，その 3 調合因子がひび割れ抵抗性に及 ぼす影響, 日本建築学会構造系論文報告集, 第 386 号, pp. $1 \sim 6,1988$.
5）六郷恵哲, 岩佐正徳, 鈴木泰生, 小柳 洽：各種コンクリー トの破壊力学パラメータ,コンクリート工学年次論文報 告集, $11-1$, pp. $247 \sim 252,1989$.

6) Li, V.C., Chan, C.M. and Ward, R. J., : A Novel Testing Technique for Post-peak Tensile Behavior of Cementitious Materials, Fracture Toughness and Fracture Energy; Test Methods for Concrete and Rock, (ed. H. Mihashi, et al. ), pp. 183 195, Balkema, 1989.

7）三橋博三：セメント系複合材料設計への破壊力学の応用, コンクリート工学年次論文報告集, 12-1, pp. 1175 1180, 1990.

8) Roelfstra, P.E. and Wittmann, F.H., : Numerical Method to Link Strain Softening with Failure of Concrete, in Fracture Toughness and Fracture Energy (ed. F.H. Wittmann), Elsevier Applied Science, pp. 163-175, 1986.

9) Li, V.C., Chan, C. M. and Leung, C. K. Y., : Experimental Determination of the Tension Softening Relations for Cementitious Composites, Cement and Concrete Research, 17, pp. 441-452, 1987.

10）六郷恵哲, 岩佐正徳, 瀬古繁喜, 小柳 洽： $J$ 積分法を 用いた曲げ試験によるコンクリートの引張軟化曲線の定 量化，第 43 回セメント技術大会講演集，pp. 398 403, 1989.

（1992 年10月 10 日原稿受理，1993 年 4 月 6 日採用决定） 